\title{
THE PRESENCE AND CHARACTERISTICS OF FEMALE DIRECTORS: HOW THEY INFLUENCE FIRM PERFORMANCE
}

\author{
Stevanus Pangestu *), Silvia Gunawan*), and Jeremy Surya Wijaya*) \\ *) Department of Accounting, Faculty of Economics and Business, Atma Jaya Catholic University of Indonesia \\ Jl. Jenderal Sudirman No. 51, Semanggi, Jakarta Selatan 12930
}

\begin{abstract}
This research aims to assess the effects of female directors' presence and characteristics on firm profitability, measured with Return on Assets. Observed characteristics include education, age, and foreign nationality. 364 publicly-traded non-financial Indonesian corporations were observed from 2013 to $2016(n=1,456)$. Our fixed effects panel regression analysis finds that the presence of female directors on the board positively influences profitability: women bring in a productive dynamic that complements the style of the male-dominated board. Meanwhile, none of the other independent variables significantly affect ROA, signifying that our results do not correspond with Upper Echelons theory. We also recommend corporations to appoint female board members based on merits and not just for the sake of diversity, as they may improve firm performance.
\end{abstract}

Keywords: female directors, firm performance, profitability, upper echelons, corporate governance

\begin{abstract}
Abstrak: Penelitian ini bertujuan menganalisis pengaruh keberadaan direktur wanita dan karakteristik direktur wanita pada kinerja perusahaan yang diukur menggunakan Return on Assets (ROA). Karakteristik yang diobservasi ialah pendidikan, usia, dan kewarganegaraan asing. Sebanyak 364 perusahaan non-keuangan terbuka di Indonesia dijadikan sampel untuk periode 2013 hingga 2016, menghasilkan 1.456 sampel. Berdasarkan analisis regresi data panel menggunakan model fixed effects, ditemukan bahwa keberadaan direktur wanita memengaruhi ROA secara positif. Wanita membawa dinamika produktifyang melengkapi dewan direksi yang didominasi oleh pria. Sedangkan variabel independen lainnya tidak memengaruhi ROA secara signifikan. Dapat disimpulkan bahwa temuan penelitian ini tidak mendukung teori Upper Echelons. Kami juga merekomendasikan perusahaan untuk menunjuk anggota dewan wanita berdasarkan prestasi dan bukan hanya demi keberagaman, karena mereka dapat meningkatkan kinerja perusahaan.
\end{abstract}

Kata kunci: dewan direksi, kinerja perusahaan, profibilitas, direktur wanita, tata kelola perusahaan

\footnotetext{
${ }^{1}$ Corresponding author:

Email: pangestu.stevanus@gmail.com
} 


\section{INTRODUCTION}

The Indonesian financial crisis in the late 1990s called for economic and structural reformation. The Enron scandal of 2000 demanded for a better corporate governance all around the world. Proper corporate governance is needed to ensure the sustainability of businesses and the prosperity of a nation's economy.

In 1999, as a by-product of the Indonesian financial crisis, the National Committee on Governance (KNKG) was established to promote the effectiveness of governance implementation in Indonesia. On a regional level, the ASEAN Capital Market Forum also spearheaded a corporate governance initiative to raise governance standards of ASEAN public corporations. This initiative was prompted by the planned establishment of ASEAN Economic Community.

The implementation of good corporate governance would allow companies to be operated on the principles of transparency, accountability, responsibility, independency, and fairness (IFC, 2014.). Such implementation may increase firm profitability, or decrease the likelihood of financial losses ( $R a d$ et al. 2013). Therefore, it is imperative that we measure the effectiveness of corporate governance to prove its usefulness. The most fundamental way to measure the performance a business is from a financial perspective, using the information that is presented on financial statements.

McKinsey, a world-renowned international management consulting firm, suggested that companies with a higher proportion of women may perform better (McKinsey and Company, 2007). This begs the question whether a female decision maker-dominated or even genderdiverse company would have performed better and prevented economic crisis. Byoun et al. (2016) argued that a diverse board would mitigate the problems caused by the principal-agent relationship in a company

There have been advances in the cause of gender diversity around the world. For example, in 2015, the Indian government requires at least one female corporate director (Chauhan and Dey, 2017). Developed countries such as France, Spain, Italy, and Netherlands had fulfilled gender representation quota. When compared to men, women are shown to be less overconfident and more careful in making management decisions (Huang and Kisgen, 2013; Levi et al. 2014). This translates to women being more risk-averse (Fauzi et al. 2017) and less likely to commit fraud. These qualities may add value to a company board of directors as they correspond to the principles of corporate governance.

Previous studies have shown that board gender diversity significantly influences firm performance. Negative relationship has been shown by Darmadi (2011) and Shehata et al. (2017), whereas Gulamhussen and Santa (2015); Ararat et al. (2015) showed positive relationship. Meanwhile Chauhan and Dey (2017) found that for India, female directors did not affect firm performance.

Attributable to the research gaps in studies about the presence of female directors, we would like to reassess the effects of the presence of female in Indonesian board of directors on firm performance, along with the influence of the characteristics of the directors, as they are inseparable from these female individuals. Board characteristics will be explored further in the following section.

Introduced in 1976 by Michael Jensen and William Meckling, this theory describes the problematic relationship between owners (or principal) and the managers (or agent) they recruit to operate the corporation. Both parties desire economic gains of their own: shareholders want their return on investment, and managers want to be compensated accordingly. Therefore, a contractual agreement has to be written in a way that clearly describes each party's rights and obligations in order to reduce conflict of interests and any wrongdoings that managers can commit. This agency relationship results in agency costs, i.e. cost that principals incur to prevent agents from prioritizing their own interests. For example, principals may offer bonus plan to agents if they achieve a certain target for financial performance. However, it does not guarantee that directors will not manage their earnings in order to obtain this bonus. For this reason, auditors are hired to ensure that a company's financial has been reported in accordance to accounting principles and standards.

In relation to the presence of female directors, agency theory suggests that a more diverse board would lead to higher independence and increase in firm value (Randoy et al. 2006) 
Upper Echelons theory was introduced in 1984 by Donald Hambrick and Phyllis Mason (Hambrick and Mason, 1984). They theorize that managerial backgrounds may predict organizational outcomes. Demographic characteristics of top management team such as age, education, and experience would influence their decision-making. The cognitive, psychological, and social characteristics of directors influence their strategic choices, which would also affect company performance, e.g. leverage, profitability.

This theory has been included in many corporate governance studies (Hambrick \& Mason, 1984). As we explore the presence of female directors on the board, we would include educational background, age, and foreign nationality characteristics in order to further assess the influence of these women on the firm.

\section{METHODS}

Our research data were obtained secondarily from the annual reports of publicly-traded non-financial Indonesian corporations. The firms were purposively selected under the consideration that they: (i) were nonfinancial corporations, (ii) published annual reports consistently and comprehensively during observation period. Financial corporations were excluded because of their highly-regulated nature, i.e. distinct from their non-financial counterparts. The data would then be analyzed on Eviews econometric package, employing panel regression analysis to test our hypotheses, which are as follows:

The presence of female directors and firm performance in: China (Liu et al. 2014), Turkey (Ararat et al. 2015), Indonesia (Triana and Asri, 2017) and large banks of OECD countries (Gulamhussen aand Santa, 2015). Luckerath-Rovers (2013) also showed that companies with female directors perform better than those without. We also take into account the Women Matter reports by McKinsey Company that have consistently shown support for more women in corporations.

\section{H1: The presence of women positively influence firm performance}

The knowledge and skills that a director possesses are crucial to the decision-making process. A higher knowledge translates to a more capable human resource in producing desired organizational outcome (Chen et al. 2012) and knowledge is attained through education.

Education has been shown to positively influence firm performance by King, Srivastav, and Williams (2016, as referenced in Pangestu, 2016) and Darmadi (2013). These findings support the Upper Echelons theory on how education background is proxy for intelligence and expertise.

H2a: Female directors'education positively influences firm performance.

In 2017, the Investor Responsibility Research Institute reported that the average age of all SP 500 boards was 62, with a minimum of 48 and maximum of 75 . These numbers represent that top managers are those in their middle ages and older. Age can be an indicator of experience and wisdom, the longer a person lives, the more professional experience and composure they possess. Chen et al. (2012) also expressed that older employees possess higher level of commitment and loyalty toward a company and as a result, this would affect firm performance.

H2b: Female directors' age positively influences firm performance.

Foreign directors have been documented to positively influence firm performance in several nations. For example, in Nigeria (Ujunwa et al. 2012) found that foreign board members increased firm performance. Similar finding was also discovered in Turkish banks by Polovina and Peasnell (2015), who found that foreign board chairman positively, influences bank profitability. These positive effects arise from the additional competencies and experience that are obtained from abroad to the dynamic on the board. Moreover, the presence of foreign directors may also send positive signal to stakeholders in terms of brand and reputation. Bremholm and Svensson (2015) also argued that board nationality diversity indicates the readiness of a firm for stricter corporate governance.

H2c: Foreign female directors positively influence firm performance 
Figure 1 presents the illustration of our research hypotheses. Meanwhile the following Table 1 displays the operational definition of independent and explanatory variables. For our regression model, we also controlled for: (i) company size, measured with natural log of total assets, (ii) leverage, measured with debt-to-equity ratio, and (iii) company age, which is defined as the difference between observation year and IPO year.

\section{RESULTS}

We analyzed data from 364 firms that were listed on the Indonesia Stock Exchange from 2013-2016, resulting in 1,456 firm-year observations. Table 2 presents the breakdown of the sample selection process. The data were then descriptively and inferentially analyzed on Eviews econometric package.

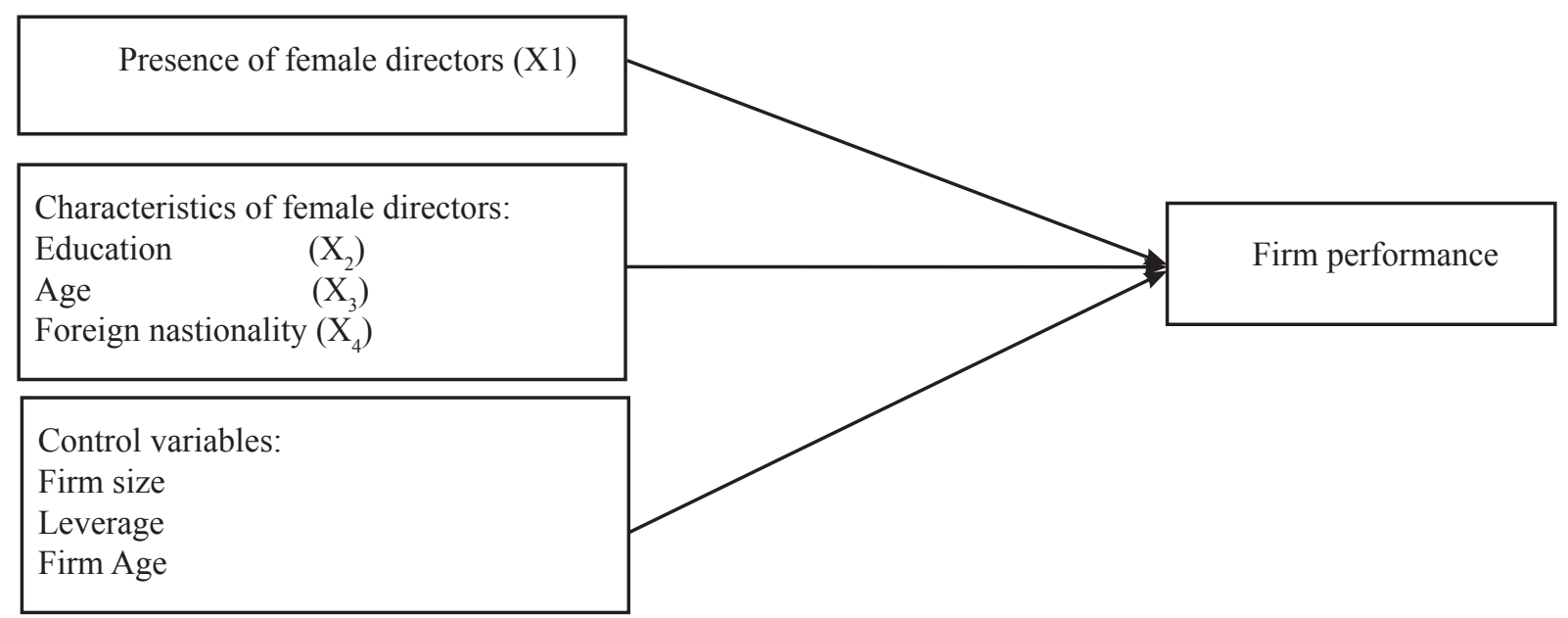

Figure 1. Research framework

Table 1. Definition of variables

\begin{tabular}{l} 
Variable \\
\hline Return on Assets (ROA) \\
Proportion of female \\
directors on board \\
(FEMALE_BOD) \\
Proportion of female \\
directors possessing \\
graduate degree (EDU)
\end{tabular}

Average age of female directors (AGE)

Proportion of foreign female directors (FOREIGN)
Definition

Profitability ratio used to measure firm performance. Many previous studies have used this such as Zen et al. (2016). It is calculated as Profit for the Year divided by Total Assets

We would measure the presence of female directors with their proportion on a board of directors (Triana and Asri, 2017). It is calculated as number of female directors for company $i$ in year $t$ divided by board size for company $i$ in year $t$

Graduate degree was selected because undergraduate degree is normally the minimum qualification for any employee in a firm. EDU is measured by dividing the number of female directors possessing graduate degree for company $i$ in year $t$ divided by number of female directors for company $i$ in year $t$ (Bennouri et al. 2018)

We measure this by totalling the age of female directors for company $i$ in year $t$ divided by the number of female directors for company $i$ in year $t$

We divide the number of foreign female directors for company $i$ in year $t$ with the number of female directors for company $i$ in year $t$ (Bennouri et al. 2018) 


\section{Descriptive Statistics}

As shown in Table 3, ROA shows that the average company earned a $3.25 \%$ return on assets during the observation period. The maximum value was achieved by PT Steady Safe Tbk. in 2016; meanwhile the minimum value was achieved by PT ICTSI Jasa Prima in 2015 .

The mean value of FEMALE_BOD shows that on average, every corporate board member comprised 12.3\% women. PT Inti Agri Resources Tbk was shown to have all-female board members and there were many corporations that had not appointed female directors $(\min .=0)$.

EDU shows that only $3.4 \%$ of board members were women who possessed master's degree. PT Sejahteraraya Anugrahjaya had the most educated female directors at $66.7 \%$.

AGE shows a mean value of 47.9 , maximum of 69 , and minimum of 29 (and a median of 48.6) where PT Borneo Lumbung Energi Metal Tbk. had the oldest female directors and PT Arpani Pratama Ocean Line Tbk. had the youngest female director on average. FOREIGN shows a mean value of $0.35 \%$, the proportion of foreign female directors in an average corporate board. The maximum value of $50 \%$ belonged to PT Keramika Indonesia Asosiasi Tbk.

For panel analysis, we first ran an ordinary least squares regression using equation:

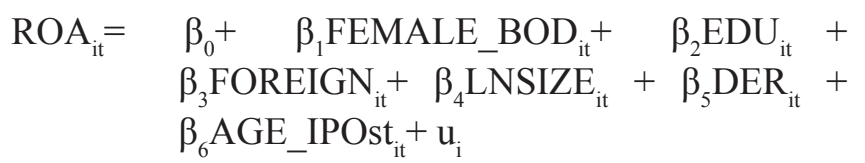

We then conducted Chow test to determine whether fixed-effects model would be better than pooled OLS. As the $\mathrm{p}$-value for the redundant fixed effects chi-square statistic was lower than $5 \%$, it can be determined that fixed-effects model would be better used for analysis.

We continued to assess our model by running Hausman test, and found that the p-value for Hausman chi-square was not greater than 5\%, therefore it can be concluded that for our analysis, fixed-effects regressor would be the best choice. Refer to Table 4 for the summary of the statistical results of the panel regression.

Table 2. Sample selection procedure

\begin{tabular}{lc}
\hline Total number of non-financial firms listed on the Indonesia Stock Exchange from 2013-2016 & 467 \\
Unavailable data & $(29)$ \\
Number of delisting's during the period & $(16)$ \\
Incomplete data & $(58)$ \\
\hline Total sample firms & 364 \\
\hline
\end{tabular}

Table 3. Descriptive statistics

\begin{tabular}{lcccc}
\hline & Mean & Maximum & Minimum & Standard Deviation \\
\hline ROA & 0.032461 & 2.192000 & -1.279101 & 0.145482 \\
FEMALE_BOD & 0.123475 & 1.000000 & 0.000000 & 0.176720 \\
EDU & 0.033837 & 0.666667 & 0.000000 & 0.090628 \\
AGE & 47.9054385 & 69.00000 & 29.000000 & 7.42733991 \\
FOREIGN & 0.003510 & 0.500000 & 0.000000 & 0.032192 \\
LNSIZE & 7.791521 & 12.47555 & 2.197225 & 1.688560 \\
DER & 0.254290 & 2.746322 & -8.830234 & 0.625287 \\
FIRM_AGE & 14.34821 & 37.00000 & 1.000000 & 8.751650 \\
\hline
\end{tabular}


Table 4. Regression analysis

\begin{tabular}{lrrr}
\hline Estimation & Pooled OLS- Equation 1 & \multicolumn{1}{c}{ Fixed Effects Model } & \multicolumn{1}{c}{ Random Effects Model } \\
\hline Constant & $-0.036929(-1.830103)^{*}$ & $-0.067002(-0.683390)$ & $-0.037007(-1.340330)$ \\
FEMALE_BOD & $0.057777(1.849763)^{*}$ & $0.142792(2.080089)^{* *}$ & $0.068074(1.750621)^{*}$ \\
EDU & $0.016982(0.366723)$ & $-0.020809(-0.206181)^{* *}$ & $0.009948(0.172141)$ \\
AGE & $-0.000468(-2.077986)^{* *}$ & $-0.000420(-0.874904)$ & $-0.000475(-1.699720)^{*}$ \\
FOREIGN & $-0.068500(-0.572553)$ & $-0.064256(-0.422945)$ & $-0.067831(-0.544084)$ \\
LNSIZE & $0.005634(2.403307)^{* *}$ & $0.035757(2.772284)^{* * *}$ & $0.005981(1.863405)^{*}$ \\
DER & $-0.003917(-0.635183)$ & $0.016415(1.799832)^{*}$ & $0.001774(0.259165)$ \\
AGE_IPO & $0.001923(4.380106)^{* * *}$ & $-0.013403(-4.613980)^{* * *}$ & $0.001576(2.592269) * * *$ \\
\hline Adjusted R2 & 0.014143 & 0.353395 & 0.0003567 \\
\hline F-statistic & $3.981907 * * *$ & $3.149224 * * *$ & $1.744063 *$ \\
\hline Redundant fixed effects & - & 1034.310667 & $(\mathrm{p}$-value=0.0000) \\
Chi-square Statistic & - & & - \\
\hline Hausman Chi-square statistic & & & $(\mathrm{p}-\mathrm{value}=0.0000)$ \\
\hline
\end{tabular}

note: $(*)$ corresponds to $10 \%$ level of significance $(* *)$ corresponds to $5 \%$ level of significance; $(* * *)$ corresponds to $10 \%$ level of significance.

\section{Presence of female directors}

We find that more female directors in a board would increase a firm's profitability. Our finding supports those of Triana and Asri (2017) in Indonesia, as well as Liu et al. (2014); Ararat et al. (2015); and Gulamhussen and Santa (2015). Furthermore, our finding signifies the importance and positive outcome of board diversity. Women bring in a productive dynamic to the game that complements the style of the male-dominated board. These female directors, who are minority, are eager to outperform their male counterparts. In return, we argue that male directors are also motivated to maintain their performance.

\section{Characteristics of female directors}

\section{Education}

Education is found not to significantly influence ROA. This is in line with the findings of Kartikaningdyah and Putri (2017). Descriptive statistics show that merely $3.4 \%$ of the female directors possess master's degree. Moreover, the majority of them did not receive university education. The $3.4 \%$ low value might render the results insignificant.

Education may be a proxy for intelligence; however we cannot associate it with firm performance. This could be the case that working environment is simply not the same as school or college environment. In educational institutions, learning is conventionally executed, i.e. more on the theoretical side. Meanwhile the professional environment is one with real challenges and consequences. It is unlike universities, where a student can process her learning in a conditioned and nearly risk-free environment.

Age

Age is shown not to influence ROA. This is in line with Tanikawa et al. (2016) and Pangestu and Dharmastuti (2018). There have been contrasting findings regarding the influence of age on firm performance. However, we find that director's age is not a determinant of organizational success. In other words, somebody's youthfulness or maturity does not guarantee effective decision-making. Therefore, it cannot become a consideration when recruiting or appointing a board member.

Age cannot be labeled as a factor when a director is appointed regardless of her merits and achievements. This defeats the purpose of using age as a measure of experience. This could cause insignificant results. Particularly when we consider many directors are not independent in Indonesian corporations, which are majorly family-owned.

\section{Foreign nationality}

ROA is not affected by the foreign nationality of female directors. Our finding is in line with Wicaksana and Astawa (2011); Pangestu and Dharmastuti (2018). This 
insignificant result may be caused by the motivation of the foreign directors' presence on the board. It may be the case that they are there merely to protect or represent the interests of foreign shareholders. Choiet al. (2012) have given evidence that the foreign board members are installed due to foreign investments.

Foreign directors also may not have company attachment as local directors do. Being appointed due to foreign investment indicates that foreign directors do not go through the career path or process as most local directors do; hence, the lack of empathy to actually perform for the company. In summary, our findings do not support Upper Echelons theory, as no board characteristic explains firm performance.

\section{Managerial Implications}

Our results stress the importance of gender diversity on board of directors. More women board members would lead to higher profitability. However, when it comes to the characteristics of female directors, we find that many female directors are not highly-educated. Moreover, the presence of foreign female directors is merely to protect the interests of foreign investors. These may cause statistically insignificant results. Companies should consider appointing or recruiting female directors on to the board as they bring on board productive dynamic. Even so, the appointment of female board members should be based on merits and not just for the sake of fulfilling diversity agenda.

\section{CONCLUSIONS AND RECOMMENDATIONS}

\section{Conclusions}

This paper aims to investigate the effects of female directors' presence and characteristics on financial performance, measured with Return on Assets (ROA) ratio. We find that the presence of female directors positively influence ROA, whereas their educational background, age, and nationality do not significantly influence ROA. It can be concluded that our findings do not support Upper Echelons theory.

\section{Recommendations}

Our investigation has a number of limitations. Further studies may want to include more upper-echelons characteristics as we only observed the primary ones. Moreover, Indonesia implements a two-tier board system. We did not observe the role of the board of commissioners.

\section{REFERENCES}

Ararat M, Aksu M, Cetin AT. 2015. How board diversity affects firm performance in emerging markets: evidence on channels in controlled firms. Corporate Governance an International Review 23(2): 83-103. https://doi.org/10.1111/ corg.12103.

Bennouri M, Chtioui T, Nagati H, Nekhili M. 2018. Female board directorship and firm performance: What really matters? Journal of Banking and Finance 88: 267-291. https://doi.org/10.1016/j. jbankfin.2017.12.010.

Bremholm A, Svensson, C. 2015. Foreign ownership and foreign directors - the effects on firm performancein Japan [thesis]. Lund: Lund University, Sweden.

Byoun S, Chang K, Kim YS. 2016. Does corporate board diversity affect corporate payout policy? Asia-Pacific Journal of Financial Studies 45(1): 48-101. https://doi.org/10.1111/ajfs.12119.

Chauhan Y. Dey DK. 2017. Do female directors really add value in Indian firms?. Journal of Multinational Financial Management 42: 24-36. https://doi.org/10.1016/j.mulfin.2017.10.005.

Chen YM, Wang Y, Sun V. 2012. Intellectual capital and organizational commitment. Personnel Review 41(3): 321-339. https://doi. org/10.1108/00483481211212968.

Choi HM, Sul W. Min SK. 2012. Foreign board membership and firm value in Korea. Management Decision 50(2): 3-3. https://doi. org/10.1108/00251741211203533.

Darmadi S. 2011. Do women in top management affect firm performance? Evidence from Indonesia. Corporate Governance: The International Journal of Business Society 13(3): 288-304. https://doi.org/10.1108/CG-12-2010-0096.

Darmadi S. 2013. Board members' education and firm performance: evidence from a developing company. International Journal of Commerce 
and Management 23(2): 113- 135. https://doi. org/10.1108/10569211311324911.

Fauzi F, Basytih A, Ho PL. 2017. Women on boardroom: does it create risk? Cogent Economics \& Finance 5(1):1-14. https://doi.org/10.1080/23322039.20 17.1325117 .

Gulamhussen MA, Santa SF.2015. Female directors in bank boardrooms and their influence on performance and risk taking. Global Finance Journal 28: 10-23. https://doi.org/10.1016/j. gfj.2015.11.002.

Hambrick DC, Mason PA. 1984. Upper echelonss: the organization as a reflection of its top managers. The Academy of Management Review 9(2): 193206. https://doi.org/10.5465/amr.1984.4277628.

Huang J, Kisgen D. 2013. Gender and corporate finance: Are male executives overconfident relative to female executive?. Finance Economy Journal 108: 822-839. https://doi.org/10.1016/j. jfineco.2012.12.005.

[IFC] International Finance Corporation. 2014. The Indonesia Corporate Governance Manual. Jakarta: IFC.

[IIRC] Investor Responsibility Research Institute. 2017. Age Diversity Within Boards of Directors of the SP 500 Companies. Newark: IIRC Institute.

Jensen MC, Meckling WH. 1976. Theory of the Firm: Managerial Behavior, Agency Costs, and Ownership Structure. Journal of Financial Economics 3: 305-360. https://doi. org/10.1016/0304-405X(76)90026-X.

Kartikaningdyah E, Putri RN. 2017. Pengaruh tax avoidance dan board diversity terhadap kinerja perusahaan dalam perspektif corporate governance. Journal of Applied Accounting and Taxation 2(2): 114-122.

King T, Srivastav A, Williams J. 2016. What's in an education? implications of CEO education for bank performance. Journal of Corporate Finance 37: 287-308. https://doi.org/10.1016/j. jcorpfin.2016.01.003.

Levi M, Li K, Zhang F. 2014. Director gender and mergers and acquisitions. Journal of Corporate Finance 28: 185-200. https://doi.org/10.1016/j. jcorpfin.2013.11.005.

Liu Y, Wei Z, Xie F. 2014. Do women directors improve firm performance in China?. Journal of Corporate Governance 28: 169-184.

Luckerath-Rovers M. 2013. Women on boards and company performance. Journal of Management and Governance 17(2): 491-509.
McKinsey, Company. 2007. Women Matter: Gender Diversity, a Corporate Performance Driver. https://www.mckinsey.com/business-functions/ organization/our-insights/gender-diversity-acorporate-performance-driver [Oct 2018]

Pangestu S. 2016. Education versus experience: which matters more for indonesian bank directors? Jurnal Manajemen 13(2): 149-157.

Pangestu S, Dharmastuti CF. 2018. What characteristics of board of directors affect indonesian bank performance?. International Journal of Accounting and Economics Studies 6(1): 48-52.

Polovina N, Pasnell K. 2015. The effect of foreign management and board membership on the performanceof foreign acquired Turkish banks. International Journal of Managerial Finance 11(3): 359-387.

Rad FH, Rajeh KZS, Botyari E, Bezminabadi GN. 2013. The The impact of corporate governance on firm's financial performance:a comparison between Iranian and Malaysian listed companies. Life Science Journal 10(6s): 49-55.

Randoy T, Thomsen S, Oxelheim L. 2006. A Nordic Perspective on Corporate Board Diversity. Nordic Innovation Center.

Shehata N, Salhin A, El-Helaly M. 2017. Board diversity and firm performance: evidence from the UK SMEs. Applied Economics 49(48): 4817-4832.

Tanikawa T, Kim S, Jung Y. 2016. Top management team diversity and firm performance: exploring a function of age. Team Performance Management: An International Journal 233(3/4): 156-170.

Triana, Asri M. 2017. The The impact of female directors on firm performance: evidence from Indonesia. Journal of Indonesian Economy dan Business 32(1): 19-32.

Ujunwa A, Okoyeuzu C, Nwakoby I. 2012. Corporate Board Diversity andFirm Performance: Evidence From Nigeria. Review of International Comparative Management 13: 605-620.

Wicaksana KAB, Astawa IP. 2011. Pengaruh kebangsaan anggota dewan pada kinerja pasar. Analisis Manajemen 5(2): 37-48

Zen N, Achsani NA, Andati T. 2016. The impact of acquisition on financial performance of pt. Abc. Indonesian Journal of Business and Entrepreneurship 2(3): 177-186. 